Available online at: http://ejournal-balitbang.kkp.go.id/index.php/ifrj
e-mail:ifrj.puslitbangkan@ @mail.com
INDONESIANFISHERIESRESEARCHJOURNAL
Volume 22 Nomor 2 December 2016
p-ISSN: 0853-8980
e-ISSN: 2502-6569

\title{
THE DISTRIBUTION AND ABUNDANCE OF DECAPOD AND FISH COMMUNITIES IN CLEVELAND BAY, AUSTRALIA
}

\author{
Andhika Prima Prasetyo*1 and Rudy Masuswo Purwoko ${ }^{1}$ \\ ${ }^{1}$ Research Center for Fisheries Research and Development, Jl. Pasir Putih II Ancol Timur, Jakarta \\ Received; Oct 24-2016 Received in revised from Dec 15-2016; Accepted Dec 16-2016
}

\begin{abstract}
Spatial and temporal variations in the fish and decapod communities were investigated at three stations in Cleveland Bay along with other zooplankton and phytoplankton communities. The linkage between biological assemblages and physical properties of the ocean was explained to develop better understanding of population dynamic of planktonic communities. Biological and physical properties data were gathered in 3 stations by 6 different trips. The results show that there is a significant association between daytime and tidal period to the abundance of planktonic communities $(P<0.05)$. Spatial distribution of fish and decapod communities are likely explained by "predator pit" and "match/mismatch" concepts to increase the survival probability along with physical properties of the ocean.
\end{abstract}

\section{Keywords: Biological oceanography; decapod and fish communities; Cleveland bay}

\section{INTRODUCTION}

Small pelagic fish are essential elements of marine ecosystems (30\% of global fisheries) due to their significant biomass at intermediate levels of the food web that play important role in connecting the lower and upper trophic levels (Cury et al., 2000; Smith et al., 2011). Moreover, the decapod species are also found in high diversity in the aquatic environments (90\% of total species) that mostly live in the sea or in adjacent brackish waters (Anger, 2001). Both groups are commercially exploited by coastal and offshore fisheries (Anger, 2001; Smith et al., 2011).

Spatial and temporal distributions of both groups are related to their life-cycle movement, such as eggs and larvae movement, settlement range movement, ontogenetic shift, relocation and migrations (nonspawning and spawning) (Pittman \& McAlpine, 2003). The influences of large-scale physical oceanography also have impact to their population dynamics, due to their relatively long period of planktonic phase (Lalli \& Parsons, 1997). Moreover, the mechanism of spawning period for mostly marine creatures during the larval stages synchronized with the annual plankton production cycle to increase survival rate
(Anger, 2001; Blaxter \& Hunter, 1982). These hypothesis (match/mismatch) are broadly accepted to determine the linkage between recruitment and plankton production (Cushing, 1990).

Cleveland Bay, Townsville-Queensland is located in the centre of Great Barrier Reef (GBR). A wind in the GBR was generated by near shore current with northward flow generated inhibited cross-shelf mixing. Additional thermocline in deep waters is driven by surface water convergence and larger turbulent eddies (Steinberg \& Great Barrier Reef Marine Park, 2007). As a result of strong southeast trades during most of the year, the GBR shelf is likely to be well mixed (Church \& Craig, 1998). The South Equatorial Current also plays crucial role and different amplitude in water transport which defined by reef density (Brinkman et al., 2001). Those conditions, create high variety of trophic status and productivity which reflected by zooplankton communities (McKinnon et al., 2005). Recent studies showed that the El Niño-Southern Oscillation (ENSO) and the North Atlantic Oscillation (NAO) reported has influenced characteristic of the GBR, especially planktonic and benthic assemblages (Kingsford et al., 2007; Steinberg \& Great Barrier Reef Marine Park, 2007). 
The recent studies in the GBR mostly covered oceanography (Eric Wolanski, 1994), primary production and energy scheme (Furnas et al., 2005), habitats and biological assemblages (Fabricius et al., 2005; Hurrey et al., 2013; Kramer et al., 2014), coral reef matters (Graham et al., 2014; Uthicke et al., 2014) and climate change impact (Fidelman et al., 2013; Sutton \& Tobin, 2011; Zeppel, 2011). However, the impact of climate change to biological assemblages is limited on the multiple effects on food web due to highly uncertainty on the response of individual marine creatures. The research's hypothesis stated that the structure of planktonic communities would follow the variability of ocean properties to maximize carrying capacity of the environment. This research examines the linkages between physical properties of the ocean on the population dynamic of planktonic assemblages, especially fish and decapod larvae in Cleveland Bay.

\section{MATERIALS AND METHODS}

\section{Time and Location}

Field surveywas conducted in Cleveland Bay, Townsville-Queensland during 28 February-1 March 2015 using RV James Kirby that consist of 6 different surveys (different time). Every measurement campaign sampled same location of 3 stations (inner, mid and outer of the bay). The taxonomy and identification of zoo- and phyto-plankton based on references from (Hartwick \& McKinnon, 2008; Slotwinski et al., 2014).

\section{Physical Sampling}

A Seabird SBE19plus conductivity-temperature-depth (CTD) profiler fitted was used to measure salinity, temperature and density at each station with samples taken from sea surface to approximately $4-10 \mathrm{~m}$ based on the bottom depth at most stations. The information of tidal chart gathered from (DTMRQ, 2014).

\section{Biological Sampling}

Large-zooplankton samples were collected by using plankton-net (200 ìm) which towed for 5 minute (2 replications). This plankton-net was equipped by flowmeter (to estimate filtered volume) and setup on the starboard side of vessel. Sample was preserved using $10 \%$ of formaldehyde. Two replicate subsamples were collected in $5 \mathrm{ml}$ of container and place it in a "Bogorov" tray to examine taxonomic diversity after refiltered using $200 \mathrm{im}$ sieve. Total individual of large-zooplankton was calculated by multiplying number of individual, which counted in sub-sample with total volume of sample, and dividing by total volume of sub-sample. Volume sample for macroplankton-net was multiplied swept area of planktonnet $\left(0.75 \times 0.65=0.49 \mathrm{~m}^{2}\right)$ and transect distance (difference in counts of flowmeter $\times 26,873$ )/999,999).

Moreover, water samples for phytoplankton and micro-zooplankton were collected at the surface by using plankton-net $(63 \mathrm{im})$ that towed for $10 \mathrm{~m} \mathrm{(2}$ replications). Both samples were preserved using 10\% of formaldehyde. In the laboratory, samples were refiltered using $60 \mathrm{im} \mathrm{sieve.} \mathrm{Two} \mathrm{replicate} \mathrm{sub-samples}$ of phytoplankton were collected in $1 \mathrm{ml}$ of container and place it in a "Sedgewick-Rafter" tray to examine taxonomic diversity. Total cells of phytoplankton were calculated by multiplying number of cells (direct observation under microscope) that counted in subsample or number of grid (1,000 grids) with total volume of sample and dividing by total volume of sub-sample. In addition, 1-5 ml sub-sample of micro-zooplankton were taken (two replicates) and examined in a small "Bogorov" tray. Total individual of micro-zooplankton followed the same calculation for large-zooplankton. Total number of zooplankton was aggregated from macro- and pico- plankton-net. As this report focus on the distribution of fish and decapod, number of zooplankton is the actual number that excluded number fish and decapod (here after called as unselected zooplankton/UZooplankton).

Furthermore, surface and bottom water were sampled to determine the difference of chlorophyll concentration in different depth by taken $5 \mathrm{~L}$ of water using Niskin Bottle. After that, $1 \mathrm{~L}$ of sample was filtered onto e"0.45 im Whatman GF/C glass fibre with a mild vacuum $(1 / 2 \mathrm{~atm}, 50 \mathrm{kPa})$. Pigments were extracted in $90 \%$ acetone following acidification techniques by ASTM (D3731-87, 2012). Spectrophotometry analysis was conducted over the range of 600 to $750 \mathrm{~nm}$ by determining light sensitivity of different pigments (Chl a-664 nm; chl b-647 nm; chls $\mathrm{c} 1$ and $\mathrm{c} 2-630 \mathrm{~nm})$. However, nutrients and underwater light was not measured due to limited time.

\section{Statistics Analysis}

The data analyses used the software Microsoft Excel 2007, SPlus 8.0, Ocean data View (ODV) 4.0. This analysis was based on non-parametric test by considering few assumptions required, such as did non-normally distributed and unequal variance data. The association between abundance of fish and decapod larvae on different stations and tidal phase (assumed as proxy of physical influence) was tested using Kruskal-Wallis rank sum test. Spearman's Rank test was also used to examine the correlation between 
abundance of copepod and number of fish and decapods larvae (Whitlock \& Schluter, 2009).

\section{RESULTS AND DISCUSSION}

\section{Results}

Phytoplankton communities are dominated by group of diatoms (69\%) and followed by cyanobacteria, diatoms and dino-flagellates $(12 \%, 10 \%$ and $9 \%$ respectively). The abundance of phytoplankton during period of survey (daytime) showed significant association (An Kruskal-Wallis rank sum test; $\mathrm{X}^{2}=$ $7.72, \mathrm{df}=2, \mathrm{p}=0.021$ ). The highest phytoplankton abundance occurred during 14:00-15:00 (1,158 \pm 701 cells/l) compared to other period (Figure 1e). A number of phytoplankton is higher in inner station ( $965 \pm 492$ cells/l) that has higher average of salinity and temperature $\left(35.8 \pm 0.1 \mathrm{psu}\right.$ and $\left.31.8 \pm 0.3^{\circ} \mathrm{C}\right)$. An abundance of phytoplankton was high during ebb-low in-group $3(1,179 \pm 357$ cells/l), and low in-group 1 during full-flood (368 \pm 226 cells/l). A Kruskal-Wallis rank sum test showed that there is insignificant association phytoplankton in different stations $\left(X^{2}=\right.$ $4.533, \mathrm{df}=2, \mathrm{p}=0.104)$. However, there is significant association phytoplankton in different phase tidal $\left(\mathrm{X}^{2}\right.$
$=10.93, \mathrm{df}=3, \mathrm{p}=0.012$ ). A Wilcoxon rank-sum test showed that there are insignificant differences between chlorophyll-a concentrations at different depths $(Z=0.33$, df $=2, p=0.738$ ) (Figure $1 b)$. Correlation test using Spearman Rank test shows that there is no significant correlation between the average of temperature and the abundance of phytoplankton $(Z=0.29, p=0.768)$.

The composition of zooplankton is dominated by copepod (84\%) and other zooplankton (14\%). The number of fish, decapod, other crustacean and other chordates are less than $5 \%$ (Figure $1 \mathrm{~b}$ and Figure 1c). The number of fishes in outer station is higher $(69 \pm 164$ ind./l) than other stations. In contrast, number of decapod and UZooplankton (exclude number of fish and decapod) phytoplankton are higher in inner station (77 \pm 144 ind./I and 60,776 \pm 45,964 ind./I, respectively) that has higher average of salinity and temperature $\left(35.8 \pm 0.1 \mathrm{psu}\right.$ and $\left.31.8 \pm 0.3^{\circ} \mathrm{C}\right)$ (Figure 1d). A Kruskal-Wallis rank sum test showed that there are insignificant association between number of fish, decapod and UZooplankton in different stations. However, number of UZooplakton that

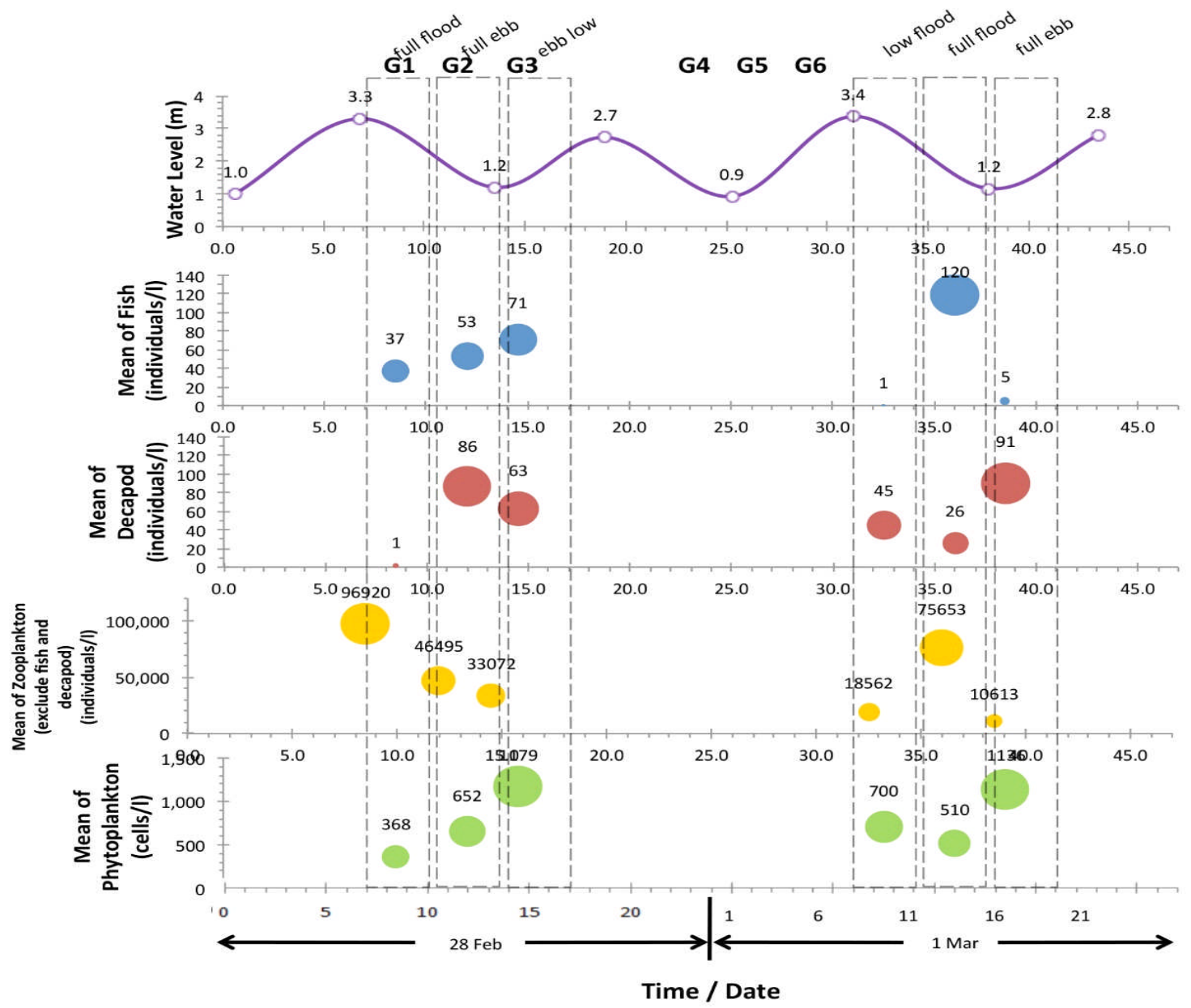

(a)

(b)

(c)

(d)

(e)

Figure 1. The influence of tide (a) to tishes (b), decapod (c), UZooplankton (d) and and phytoplankton (e) communities. 
dominated by copepod likely has less significant association with stations $\left(X^{2}=5.64, d f=2, p=0.059\right)$.

The distribution of fish depends on the group, which reflected influence of tidal proxy of time. A number of fishes were high during trip of group 5 when full-flood happened (120 \pm 197 ind./l) and low during low-flood in-group 4 (1 \pm 1 ind./I) (Figure 1b). In addition, during full-ebb in group 6 number of decapod were high (91 \pm 142 ind./I), but UZooplankton was low $(10,614 \pm 2,781$ ind./I). Similar pattern also showed in group 1 when the tide in full-flood phase, number of decapod were low (2 \pm 2 ind./I), however, number of Uzooplankton were high (96,920 $\pm 68,656$ ind./I) (Figure 1c-d). A Kruskal-Wallis rank sum test showed that there are significant association between number of fish, decapod and UZooplankton in different phase of tidal.

Longitudinal section showed that temperature near the coastal was higher than in the open ocean. Moreover, profile indicates the subduction process of cool water from open waters to coastal water that probably signal of upwelling (Figure 2a). Moreover, generally high salinity waters moved to deeper water and filled by low saline water from the ocean (Figure 2b). Low-density waters distributed near the coastal and mixed with high dense of waters mass from the bottom of the open ocean (Figure 2a). Correlation test using Spearman Rank test showed that there is insignificant correlation between the average of temperature and number of fishes and decapod. However, there was significant correlation (positive)
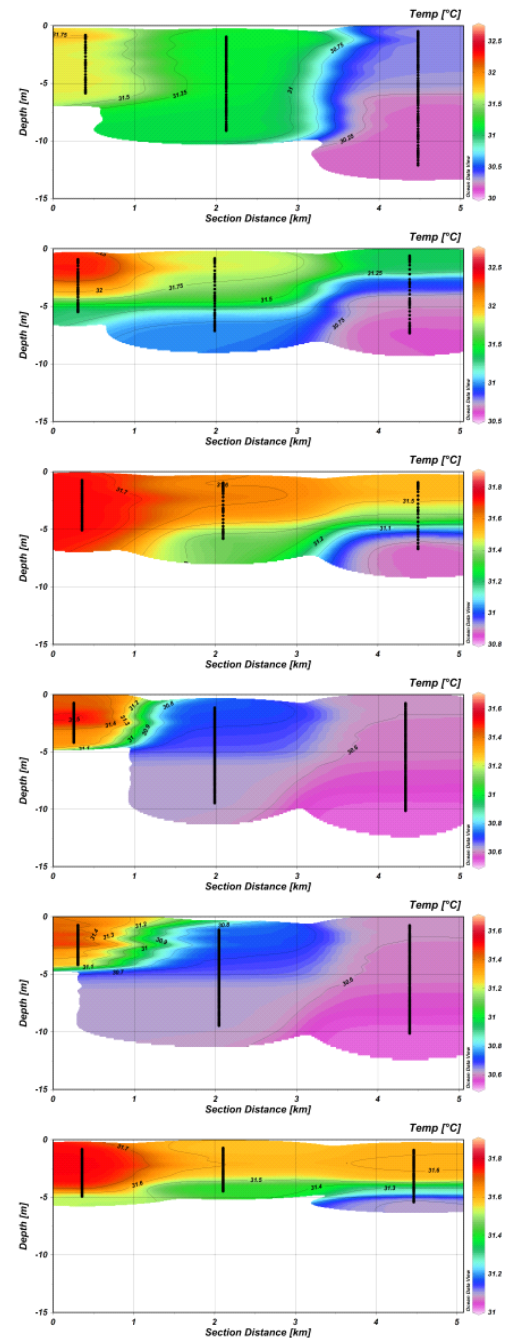

(a) Temperature $\left({ }^{\circ} \mathrm{C}\right)$
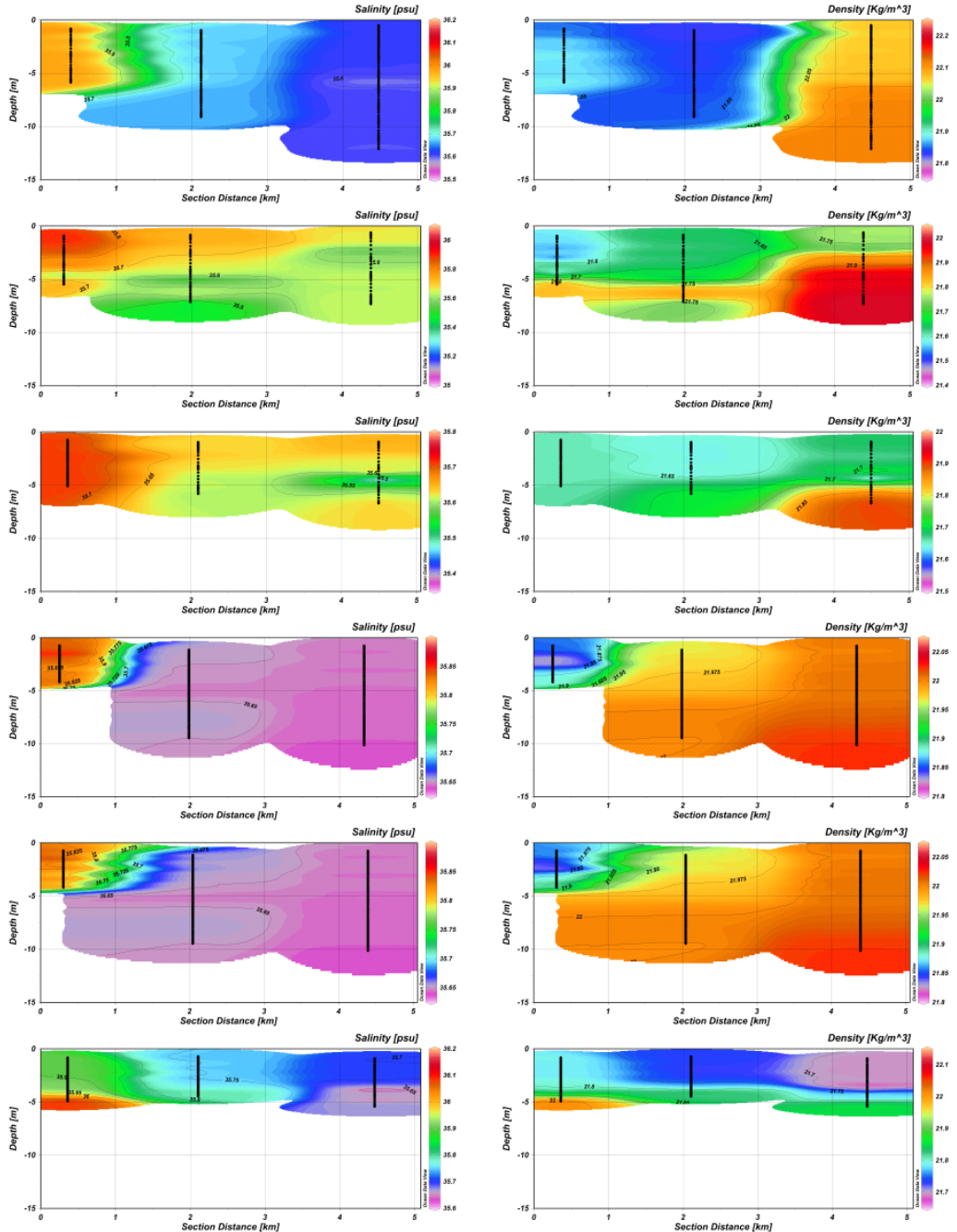

(b) Salinity (psu)

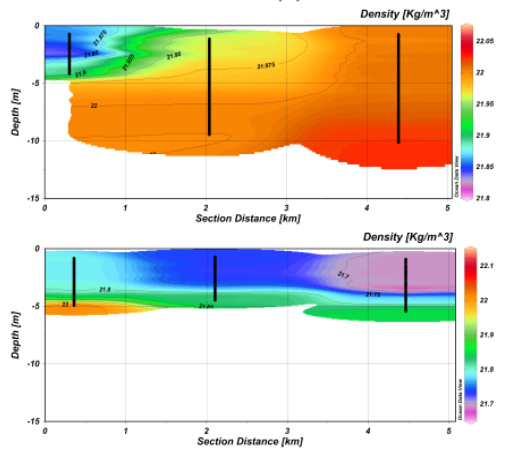

(c) Density $\left(\mathrm{Kg} / \mathrm{m}^{\wedge} 3\right)$

Figure 2. Section profile of temperature (a), salinity (b) and density (c) in different station (inner station: left to outer station: right). 
between the mean of temperature and zooplankton abundance $(Z=2.09, p=0.036, r=0.354)$.

\section{Discussion}

Planktonic assemblages are crucial as a basis of food web in the ocean ecosystem (Smith et al., 2011). This assemblage was considerably influenced by the dynamic of physical properties in the ocean, such as solar radiation, salinity, temperature and nutrient (Lalli \& Parsons, 1997). Phytoplankton as primary producer in the ocean is mainly driven by solar intensity. Due to the lack of underwater light data, we assume that the solar intensity gradually decrease as the depth increase (Strickland, 1958). This study showed the significant signature of temporal variety of phytoplankton abundance during survey (an KruskalWallis rank sum test; $X 2=7.72$, df $=2, p=0.021$ ). The visible spectrum (about $400-700 \mathrm{~nm}$ ) of solar radiation has been penetrated to sea surface (around $50 \%$ ) which used for photosynthesis (Miller \& Wheeler, 2012). Spatial variation showed that high nutrient supply commes from mainland through run-off led to high abundance of phytoplankton in the inner station (high salinity and temperature). Nutrient availability influenced the growth rate of phytoplankton, however, mostly nutrient was high deeper layer (Lalli \& Parsons, 1997). The information on nutrient distribution was substituted by concentration of chlorophyll-a. Since, in the tropical waters chlorophyll-a was used to examine the nutrient richness of the ocean (Takeda, 1998). The upwelling generated surface fertilization through mass transport. The upwelling in the GBR mostly influenced by East Australian Current flowing south (McKinnon \& Thorrold, 1993). During ebb-low period of tidal, number of phytoplankton increased due to an increase in shoal-channel exchange (Kimmerer et al., 1998).

The result showed that there was no significant different in the vertical distribution of chlorophyll-a. It could be argued that the waters mass during survey has been well mixed, therefore nutrient supply in the surface and bottom are similar (deeper nutricline). Similar argument was stated by E. Wolanski \& Ridd (1990) that Inner shelf waters are considerable well mixed. Moreover, bottom water sample was taken from relatively swallow waters $(4-7 \mathrm{~m})$ and the light able to penetrate up to $150 \mathrm{~m}$ (Kramer et al., 2014; Lalli \& Parsons, 1997) by considering low turbidity during survey. However, generally the chlorophyll-a concentration was high in the outer station. It suggests the grazing process by zooplankton, is due to high abundance of zooplankton in inner station.
In addition, zooplankton (exclude fish and decapod) that mostly represented by copepod (84\%) reported that high abundance occurs in inner station during full-flood phase (Figure 1d). The pattern is followed by an increase of phytoplankton in the same station. Food availability estimated as trigger of high abundance (Hurrey et al., 2013) and indirect effect of terrestrial run-off (McKinnon \& Thorrold, 1993). Zooplankton plays important role in aquatic ecosystem, such as grazers on the primary production and energy flux to higher tropic level (fish, birds and whale populations) (Levinsen \& Nielsen, 2002).

Population dynamic of zooplankton is also influenced by temperature (significant correlation; Figure 2b). The signal of upwelling probably appeared by considering the subduction process of cool water from open waters to coastal water (Figure 2a). Temperature likely effected metabolic rate of organism (Ikeda et al., 2001). High temperature water likely increased a number of zooplankton, especially copepod (Southward et al., 1995). Some species of zooplankton did diel vertical migration which aimed for adaptation, grazing and communicating (Lalli \& Parsons, 1997). An increase in salinity led to an increase in number of zooplankton (Vuorinen et al., 1998) and also generated stress level (Gaudy et al., 2000). As the longitudinal profile showed the movement of the high salinity waters to deeper water and filled by low saline water from the ocean (Figure $2 b$ ). The studies stated that the differences of consumption rate of copepod as herbivores and carnivores by $65 \%$ and $310 \%$ of their body weight (Ikeda et al., 2001; McKinnon et al., 2005).

Fish and decapod groups are commonly called as nekton that is important as commercial commodities, such as herring, shrimp and crab. Decapod referred to crustaceans that carapace along the back and covering the gills (Miller \& Wheeler, 2012). Decapod has two life stages, i.e. benthic juvenile and pelagic larvae which is determined different morphology feature and habits (Anger, 2001). This study found that decapod mostly occured in the high abundance in inner station during full-ebb tidal phase. It is likely due to habitat fragmentation (Anger, 2001) and food availability (Cushing, 1990). Decapod larvae have high variety of food sources, such organic solutes, detrital matter, bacteria, protozoans and an enormous diversity of metazoan zooplankton (Anger, 2001). It will drive by larvae stages and food selectivity. Decapod consumed planktonic algae $(20-200 \mu \mathrm{m})$, such as diatoms and also zooplankton (copepods, cirripedes, mollusc and echinoderm larva) (Anger, 2001). However, during the early phyllosoma larvae of decapod consumed chaetognaths, fish larvae and 
hydromedusae (Anger, 2001). The main influence of temperature and salinity to distribution of decapod is on the energy partitioning. The high salinity would lead to high stress on energy assimilation. By following pattern, it showed that high abundance of decapod followed by low density of copepod. It was argued as "predator pit" concept that to avoid predator by moving into less appropriate feeding area (Bakun, 2006).

As planktonic stages, fish was highly vulnerable as prey of other zooplankton, such decapod and copepod (Waite et al., 2014). Therefore, "predator pit" concept also could explain it due to high density of fish found in the station that have low abundance of decapod and copepod. In addition, high density of fish occurred during full-flood when waters mass started to flushed and indicated by low temperature. During low-flood tidal phase when temperature was high, the abundance of fish was low as well as density of UZooplankton. It was likely follow "match / mismatch" concept (Cushing, 1990) to ensure high survival probability.

\section{CONCLUSION}

There was a significant association between the abundance of planktonic communities to time and tidal period $(P<0.05)$. The concept of "predator pit" and "match/mismatch"possibly explained the spatial distribution of fish and decapod communities. That phenomenon seems be related to the likelihood of survival probability and physical properties of the ocean. The further investigation is needed to examine the seasonal trend and the impact of climate change to the variation of planktonic communities.

\section{ACKOWLEDGMENTS}

We would like to thank the support of Department of Foreign Affairs and Trade (DFAT), Australia to provide funding through Australian Awards Scholarship. Also, we thank to Dr. Orpha Bellwood for his constructive review and comment and Biological Oceanography Class (MB5055) in James Cook University.

\section{REFERENCES}

Anger, K. (2001). The Biology of Decapod Crustacean Larvae. Lisse, The Netherlands: A.A. Balkema.

Bakun, A. (2006). Fronts and eddies as key structures in the habitat of marine fish larvae: opportunity, adaptive response and competitive advantage. Scientia Marina, 70, 105-122.
Blaxter, J. H. S., \& Hunter, J. R. (1982). The Biology of the Clupeoid Fishes. Advances in Marine Biology, 20, 1-223. doi:10.1016/S00652881(08)60140-6

Brinkman, R., Wolanski, E., Deleersnijder, E., F, M., \& Skirving, W. (2001). Oceanic inflow from the Coral Sea into the Great Barrier Reef. Estuarine, Coastal and Shelf Science, 54, 655-668.

Church, J., \& Craig, P. (1998). Australia's Shelf Seas: Diversity and Complexity. In A. R. Robinson \& K. H. Brink (Eds.), The Sea (Vol. 11, pp. 933-964).

Cury, P., Bakun, A., Crawford, R., Jarre, A., Quinones, R., Shannon, L., \& Verheye, H. (2000). Small pelagics in upwelling system: petterns of interaction and structural changes in "wasp-waist" ecosystems. ICES Journal of Marine Science, 57(3), 603-618. doi:10.1006/jmsc.2000.0712

Cushing, D. H. (1990). Plankton Production and Yearclass Strength in Fish Populations: an Update of the Match/ $\mathrm{M}$ ismatc $\mathrm{h}$ Hypothesis. Advances in Marine Biology, 26, 249-293.

D3731-87, A. (2012). Standard Practices for Measurement of Chlorophyll Content of Algae in Surface Waters. West Conshohocken, PA: ASTM International.

DTMRQ. (2014). Queensland Tide Tables Standard Port Tide Times 2015. Brisbane: Department of Transport and Main Roads.

Fabricius, K., De'ath, G., McCook, L., Turak, E., \& Williams, D. M. (2005). Changes in algal, coral and fish assemblages along water quality gradients on the inshore Great Barrier Reef. Marine pollution bulletin, 51(1), 384-398. doi:10.1016/ j.marpolbul.2004.10.041

Fidelman, P. I. J., Leitch, A. M., \& Nelson, D. R. (2013). Unpacking multilevel adaptation to climate change in the Great Barrier Reef, Australia. Global Environmental Change, 23(4), 800-812. doi:10.1016/j.gloenvcha.2013.02.016

Furnas, M., Mitchell, A., Skuza, M., \& Brodie, J. (2005). In the other $90 \%$ : phytoplankton responses to enhanced nutrient availability in the Great Barrier Reef Lagoon. Marine Pollution Bulletin, 51(1), 253265. doi:10.1016/j.marpolbul.2004.11.010

Gaudy, R., Cervetto, G., \& Pagano, M. (2000). Comparison of the metabolism of Acartia clausi 
and $A$. tonsa: influence of temperature and salinity. Journal of experimental marine biology and ecology, 247(1), 51-65. .

Graham, N. A. J., Chong-Seng, K. M., Huchery, C., Januchowski-Hartley, F. A., \& Nash, K. L. (2014). Coral reef community composition in the context of disturbance history on the Great Barrier Reef, Australia. PloS one, 9(7), e101204.

Hartwick, R. Laboratory Guide to The Plankton of The Townsville Region. Departement of Marine Biology. James Cook University.

Hurrey, L. P., Pitcher, C. R., Lovelock, C. E., \& Schmidt, S. (2013). Macroalgal species richness and assemblage composition of the Great Barrier Reef seabed. Marine Ecology Progress Series, 492, 69-83. doi:10.3354/meps 10366

Ikeda, T., Kanno, Y., Ozaki, K., \& Shinada, A. (2001). Metabolic rates of epipelagic marine copepods as a function of body mass and temperature. Marine Biology, 139(3), 587-596.

Kimmerer, W. J., Burau, J. R., \& Bennett, W. A. (1998). Tidally oriented vertical migration and position maintenance of zooplankton in a temperate estuary. Limnology Oceanography, 43(7), 16971709.

Kingsford, M. J., Welch, D. J., \& Great Barrier Reef Marine Park, A. (2007). Chapter 18: Vulnerability of pelagic systems of the Great Barrier Reef to climate change (ISBN9781876945619). Retrieved from Townsville: http://hdl.handle.net/11017/550

Kramer, M. J., Bellwood, D. R., \& Bellwood, O. (2014). Large-scale spatial variation in epilithic algal matrix cryptofaunal assemblages on the Great Barrier Reef. Marine Biology, 161(9), 2183-2190. doi:10.1007/s00227-014-2495-6

Lalli, C. M., \& Parsons, T. R. (1997). Biological oceanography: an introduction. - 2nd ed. Oxford, UK: Elsevier Butterworth-Heinemann.

Levinsen, H., \& Nielsen, T. G. (2002). The Trophic Role of Marine Pelagic Ciliates and Heterotrophic Dinoflagellates in Arctic and Temperate Coastal Ecosystems: A Cross-Latitude Comparison. Limnology and Oceanography, 47(2), 427-443.

Kingford, M.J., Helman, H.K., Alexander, C. G., \& McKinnon, A. D. (2008). Plankton. In J. A.
Hutchings, M. J. Kingsford, \& O. Hoegh-Guldberg (Eds.), The Great Barrier Reef: Biology, Environment and Management (pp. 129-144). Collingwood, Vic.: CSIRO Press.

McKinnon, A. D., Duggan, S., \& De'ath, G. (2005). Mesozooplankton dynamics in nearshore waters of the Great Barrier Reef. Estuarine, Coastal and Shelf Science, 63, 497-511. doi:10.1016/ j.ecss.2004.12.011

McKinnon, A. D., \& Thorrold, S. R. (1993). Zooplankton community structure and copepod egg production in coastal waters of the central Great Barrier Reef lagoon. Journal of Plankton Research, 15, 1,387381,411 .

Miller, C. B., \& Wheeler, P. A. (2012). Biological Oceanography 2nd ed. Oxford, UK: John Wiley \& Sons.

Pittman, S. J., \& McAlpine, C. A. (2003). Movements of marine fish and decapod crustaceans: process, theory and application. Advances in Marine Biology, 44, 205-294. doi:10.1016/S0065-2881(03)440042

Slotwinski, A., Coman, F., \& Richardson, A. J. (2014). Introductory Guide to Zooplankton Identification. Brisbane: CSIRO Publishing.

Smith, A., Brown, C., Bulman, C., Fulton, E., Jhonson, P., Kaplan, I., . . Tam, J. (2011). Impacts of Fishing Low-Trophic Level Species on Marine Ecosystems. Science, 333(6046), 1147-1150. doi:10.1126/ science.1209395

Steinberg, C., \& Great Barrier Reef Marine Park, A. (2007). Chapter 3: Impacts of climate change on the physical oceanography of the Great Barrier Reef (ISBN9781876945619). Retrieved from Townsville: http://hdl.handle.net/11017/536

Strickland, J. D. H. (1958). Solar Radiation Penetrating the Ocean. A Review of Requirements, Data and Methods of Measurement, with Particular Reference to Photosynthetic Productivity. Journal of the Fisheries Research Board of Canada, 15(3), 453-493. doi:10.1139/f58-022

Sutton, S. G., \& Tobin, R. C. (2011). Constraints on community engagement with Great Barrier Reef climate change reduction and mitigation. Global Environmental Change, 21(3), 894-905. doi:10.1016/j.gloenvcha.2011.05.006 
Takeda, S. (1998). Influence of iron availability on nutrient consumption ratio of diatoms in oceanic waters. Nature, 393, 774-777. doi:10.1038/31674

Uthicke, S., Furnas, M., \& Lønborg, C. (2014). Coral reefs on the edge? Carbon chemistry on inshore reefs of the great barrier reef. PloS one, 9(10), e109092.

Vuorinen, I., Hänninen, J., Viitasalo, M., Helminen, U., \& Kuosa, H. (1998). Proportion of copepod biomass declines with decreasing salinity in the Baltic Sea. ICES Journal of Marine Science, 55(4), 767-774.

Waite, A. M., Beckley, L. E., Jeffs, A., Saunders, M., Sawstrom, C., O'Rorke, R., ... Nguyen, M. (2014).
Biological Oceanography of Western Rock Lobster Larvae. Perth: The University of Western Australia.

Whitlock, M., \& Schluter, D. (2009). The analysis of biological data. Greenwood Village, Colo: Roberts and Co. Publishers.

Wolanski, E. (1994). Physical Oceanographic Processes of the Great Barrier Reef: CRC Press.

Wolanski, E., \& Ridd, P. (1990). Mixing and trapping in Australian tropical coastal waters. Coastal Estuarine Study, 38, 165-183.

Zeppel, H. (2011). Climate Change Workshops for Great Barrier Reef Marine Tourism Operators. Tourism in Marine Environments, 7(2), 95-98. doi:10.3727/154427311X13038402065901. 